Print ISSN: 2233-4165 / Online ISSN: 2233-5382

doi:http://dx.doi.org/10.13106/ijidb.2018.vol9.no5.17

\title{
Effects of Website Characteristics and Delivery Service Quality on Repurchase Intention*
}

\author{
Wenqian Dai**, Jong-Ho Lee*** \\ Received: March 15, 2018. Revised: May 6, 2018. Accepted: May 15, 2018.
}

\section{Abstract}

Purpose - Through the analysis of the characteristics of overseas direct purchase websites and the relevant empirical analysis of the quality of service delivery, the activated theory/strategy and significance of the overseas direct purchase are sorted out.

Research design, data, and methodology - In the process, to make more effective analysis, several analysis tools and analysis programmes are used, IBM SPSS Statistics 23.0 and IBM SPSS AMOS 23.0.

Results - Among the characteristics of the overseas direct purchase website, the security, convenience and information provided by the overseas direct purchase have already had a positive impact on the satisfaction. The quality of the delivery service is composed of four factors: rapidity, reliability, intimacy and correctness. The research results indicate that the satisfaction level has a positive impact on the re-purchase intention.

Conclusions - The significance of this study has the characteristics of overseas direct purchase sites which have confirmed that security convenience and intelligence availability have a positive impact on satisfaction and re-purchase intent. It is important to have a safe and reliable access to shopping sites on overseas direct purchase sites. In the characteristics of overseas direct purchase sites, the interaction have no positive effect on satisfaction and re-purchase intention.

Keywords: Overseas Direct Shopping, Website Characteristics, Service Quality, Satisfaction, Repurchase Intention.

JEL Classifications: M10, M15, M19.

\section{Introduction}

With the booming in current online shopping, "overseas purchasing" has been talked about frequently as a way of resource integration(Tian et al., 2017). In many brand products, some own lower prices in foreign countries, some are not on sale in China, and while some in shortage in China. In order to solve similar problems and to expand the consumers' purchase scope(Shin, 2015), "overseas purchasing" came into being at the right moment(Suk, 2016).

* This work was modified and abbreviated from Dai's Master Thesis.

** First Author, Master of E-Commerce, Dept. of Electronic Commerce, Kongju National University, Korea.

Tel: +82-41-850-8255, E-mail: dai0630@naver.com

*** Corresponding Author, Professor, Dept. of Electronic Commerce, Kongju National University, Korea.

Tel: +82-41-850-8257, E-mail: leejh@kongju.ac.kr
Online shopping overseas refers to overseas shopping(Hong \& Park, 2017), which means that through the Internet to retrieve overseas commodity's information(Kim \& Park, 2016), and issue a shopping request through the electronic order (Bai et al., 2016), and then fill in the private credit card number(Kim et al., 2017), afterwards the overseas shopping site will deliver goods through international express(Lim \& Hong, 2017), or by the transit company to collect goods and forward the goods to China(Cho, 2014). The general payment method is delivery on payment: online credit card payment, PayPal account payment(Wu \& Lee, 2017).

So the purpose of this study are as follows.

First, Taking the characteristics of overseas direct purchase sites and delivery service quality as the center, it conducts the relevant analysis on the related factors about the satisfaction and the re-purchase intention, so as to grasp the consumer's influence on the re-purchase intentions.

Second, Through the analysis of the characteristics of overseas direct purchase websites and the relevant empirical 
analysis of the quality of service delivery, the activated theory/strategy and significance of the overseas direct purchase are sorted out.

\section{Theoretical Background}

China also has lots of overseas purchasing site and websites of special offers, you can learn the detailed information of the overseas purchasing process and related raiders through these websites(Kim \& Lim, 2015), and these sites can also provide purchasing service $(\mathrm{Wu} \&$ Lee, 2017).

In addition, there are the provisions of overseas time-limited discount navigation service to bring together the daily discount items on specific website, and the classification of a wide variety of goods in accordance with the category, saving the users' time, build better and safer channels for users and these sites(Tian \& Lee, 2016).

There are also some ancillary sites or tools. Through these sites, users can easily access to prices, evaluation information, as well as the products' popularity of the same goods in the mainstream electric business sites at home and abroad(Kim et al., 2016).

Besides, it also provides one-key query function on the logistics information of Overseas shopping goods, through the provision of domestic and international express information inquiry service for major transit companies and YOTO, ZTO, STO, HT, Yunda and EMS, help people with express query syndrome out of the anxiety, makes the overseas shopping online easier(Wu \& Lee, 2017).

The website based on the characteristics of the study of literature data for review. The site of the existing the research of online shopping site, most of the characteristics of the process. The research tendency of the foreign office. "and" satisfaction and the characteristics of the procurement "to study the concentration observed. The ball straight to the site and the success factors, and to judge it. The universal meaning of convenience is convenient and easy to use or use, and the universal definition of convenience means comfortable and good characteristics(Lee et al., 2015).

$\mathrm{Wu}$ and Lee(2016) applied the extended technology acceptance model to smartphone applications with convenience, response speed, design quality, reliability, and connectivity as exogenous variables. The results of the study proved that convenience, design quality, response speed, and connectivity have a beneficial effect on customer satisfaction. In this study, convenience is defined as the degree to which consumers can easily access web apps, and convenience has a positive $(+)$ effect on the satisfaction of web apps. Interactivity is a characteristic of the communication process, which defines the degree to which messages are exchanged in a series of message exchanges to the extent that the messages follow the previous messages, and emphasizes the consistency of messages.

\section{Research Model and Hypotheses}

\subsection{Research Model}

We surveyed previous studies on repurchase intention through overseas direct shopping and finalized the variables like web site characteristics and delivery service quality based on previous reviews. Web site characteristics are security, convenience, interactivity, information provided. And the variables of delivery service quality are rapidness, reliability, intimacy, correctness. The rest ones are satisfaction and repurchase intention. The research model is as follows(<Figure $1>$ ).

Based on the above designed studies, after deriving hypotheses on web site characteristics and delivery service quality, we analyzed the influence of repurchase intention with mediating of satisfaction

\subsection{Research Hypotheses}

\subsubsection{Hypotheses on web site characteristics}

Among the web site characteristics, the important variables are security, convenience, interactivity, information provided. and delivery service quality. These are derived from the studies like Kim et al.(2004), Laio et al.(2007), Kim and Chang(2007) etc.. Therefore following hypotheses are established.

$<\mathrm{H} 1>$ the web site characteristics will make positive influence on satisfaction.

$<\mathrm{H} 1-1>$ security will make positive influence on satisfaction.

$<\mathrm{H} 1-2>$ convenience will make positive influence on satisfaction.

$<\mathrm{H} 1-3>$ interactivity will make positive influence on satisfaction.

$<\mathrm{H} 1-4>$ information provided will make positive influence on satisfaction.

$<\mathrm{H} 2>$ the web site characteristics will make affirmative influence on repurchase intention.

$<\mathrm{H} 2-1>$ security will make affirmative influence on repurchase intention.

$<\mathrm{H} 2-2>$ convenience will make affirmative influence on repurchase intention.

$<\mathrm{H} 2-3>$ interactivity will make affirmative influence on repurchase intention.

$<\mathrm{H} 2-4>$ information provided will make affirmative influence on repurchase intention. 


\subsubsection{Hypotheses on delivery service quality}

Among the delivery service quality, the founded major variables are rapidness, reliability, intimacy, correctness. and delivery service quality. At the aspects of delivery service marketing area, previous studies showed that variables of delivery service quality are precedent ones on satisfaction and repurchase intention. These are derived from the studies like Crosby et al.(1990) etc. So following hypotheses are established.

$<\mathrm{H} 3>$ the delivery service quality will make positive influence on satisfaction.

$<\mathrm{H} 3-1>$ rapidness will make positive influence on satisfaction.

$<\mathrm{H} 3-2>$ reliability will make positive influence on satisfaction.

$<\mathrm{H} 3-3>$ intimacy will make positive influence on satisfaction.

$<$ H3-4> correctness will make positive influence on satisfaction.

$<\mathrm{H} 4>$ the delivery service quality will make affirmative influence on repurchase intention.

$<\mathrm{H} 4-1>$ rapidness will make affirmative influence on repurchase intention.

$<$ H4-2> reliability will make affirmative influence on repurchase intention.

$<\mathrm{H} 4-3>$ intimacy will make affirmative influence on repurchase intention.

$<$ H4-4> correctness will make affirmative influence on repurchase intention.

$<\mathrm{H} 5>$ satisfaction will make affirmative influence on repurchase intention.

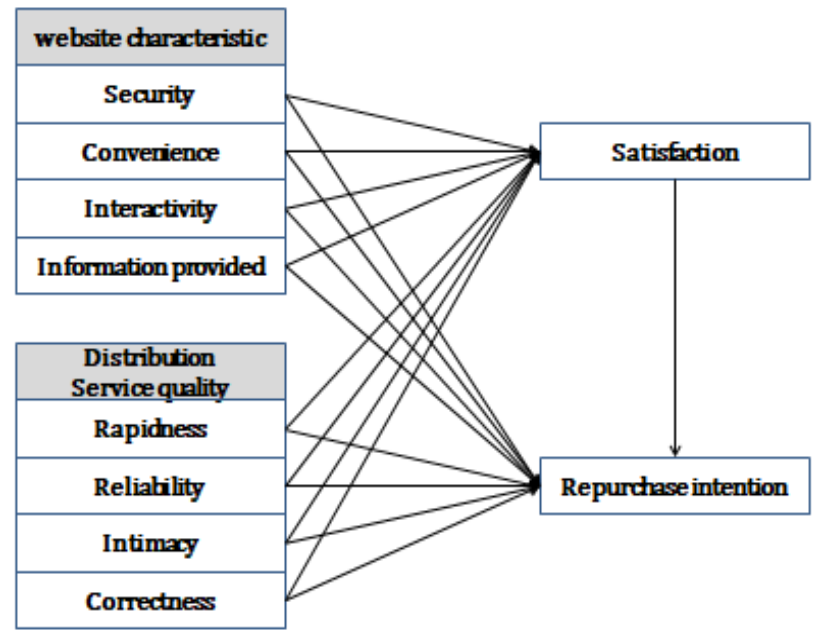

<Figure 1> Research Model

\section{Empirical Analysis}

\subsection{Data Collection and Measurement}

We surveyed Chinese users who have used foreign direct shopping malls. The survey was conducted for 20 days from March 12th to April 1th, 2017. The questionnaires were distributed to students, housewives, professionals, selfemployed, and public officials in China such as Beijing, Zhengzhou, Wuhan, and Guangzhou through online research specialists. Collection. The questionnaire collected 300 copies, and 272 copies were used for the empirical analysis except for 28 copies. In the process, to make more effective analysis, several analysis tools and analysis programmes are used, IBM SPSS Statistics 23.0 and IBM SPSS AMOS 23.0.

Of the 272 respondents, 197 (72.43\%) were female. More than a third of the respondents $(n=128,47.0 \%)$ were $20-29$ years old, while $37.1 \%$ were $35-44$ years old $(n=101), 6.62 \%$ were 40-49 years old ( $n=18), 6.62 \%$ were 50 s or older old( $n=18)$, and $7.72 \%$ were younger than age $20(n=21)$.

More than a third of the respondents $(n=114,41.91 \%)$ held a University (Bachelor's), while $32.72 \%$ held a two-year University student $(\mathrm{n}=89)$, and around $19.12 \%$ had done Master's or higher degree $(n=52), 103$ (37.87\%) were Company employee(<Table 1>).

$<$ Table 1> Demographic Characteristics

\begin{tabular}{|c|c|c|c|}
\hline \multicolumn{2}{|r|}{ Classification } & Frequency & Percentage \\
\hline \multirow{2}{*}{ Gender } & Male & 75 & 27.57 \\
\hline & Female & 197 & 72.43 \\
\hline \multirow{5}{*}{ Age } & Below 20s & 21 & 7.72 \\
\hline & $20 s$ & 128 & 47.06 \\
\hline & $30 s$ & 101 & 37.13 \\
\hline & $40 s$ & 18 & 6.62 \\
\hline & 50 s or older & 4 & 1.47 \\
\hline \multirow{4}{*}{ Education } & High school graduate & 17 & 6.25 \\
\hline & University student & 89 & 32.72 \\
\hline & University (Bachelor's) & 114 & 41.91 \\
\hline & Master's or higher degree & 52 & 19.12 \\
\hline \multirow{6}{*}{ Occupation } & Student & 68 & 25.00 \\
\hline & Housewife & 45 & 16.54 \\
\hline & Company employee & 103 & 37.87 \\
\hline & Freelancer & 34 & 12.50 \\
\hline & Public servant & 19 & 6.99 \\
\hline & Other & 5 & 1.84 \\
\hline
\end{tabular}

More than a third of the respondents ( $n=102,37.5 \%)$ Past Experiences were Above 12 month Less than 18 month, monthly Time of Use were 1-3 time( $n=134,49.26 \%)$. more than $41.54 \%$ of the respondents $(n=113)$ held Software is the T-mall Global, The Motivation of use were almost the respondents was Genuine guarantee( $n=98,36.03 \%)$ and Cheap price $(n=110,40.44 \%)(<$ Table $2>)$. 
<Table 2> Usage Statistics

\begin{tabular}{|c|c|c|c|}
\hline \multicolumn{2}{|c|}{ Classification } & Frequency & Percentage \\
\hline \multirow{6}{*}{$\begin{array}{c}\text { Past } \\
\text { Experiences }\end{array}$} & Less than 1 month & 11 & 4.04 \\
\hline & $\begin{array}{l}\text { Above } 1 \text { month - } \\
\text { Less than } 6 \text { month }\end{array}$ & 36 & 13.24 \\
\hline & $\begin{array}{c}\text { Above } 6 \text { month - } \\
\text { Less than } 12 \text { month }\end{array}$ & 41 & 15.07 \\
\hline & $\begin{array}{l}\text { Above } 12 \text { month - } \\
\text { Less than } 18 \text { month }\end{array}$ & 102 & 37.50 \\
\hline & $\begin{array}{l}\text { Above } 12 \text { month - } \\
\text { Less than } 24 \text { month }\end{array}$ & 59 & 21.69 \\
\hline & Above 24 month & 23 & 8.46 \\
\hline \multirow{4}{*}{$\begin{array}{l}\text { monthly } \\
\text { Time of } \\
\text { Use }\end{array}$} & 1-3 times & 134 & 49.26 \\
\hline & $4-5$ times & 82 & 30.15 \\
\hline & 6-10 times & 49 & 18.01 \\
\hline & Above 10 times & 7 & 2.57 \\
\hline \multirow{5}{*}{ Software } & T-MALL Global & 113 & 41.54 \\
\hline & JD Global & 77 & 28.31 \\
\hline & SuNing & 52 & 19.12 \\
\hline & VIPS & 9 & 3.31 \\
\hline & Other & 21 & 7.72 \\
\hline \multirow{4}{*}{$\begin{array}{c}\text { Motivation } \\
\text { of Use }\end{array}$} & Genuine guarantee & 98 & 36.03 \\
\hline & cheap price & 110 & 40.44 \\
\hline & The best service & 52 & 19.12 \\
\hline & other & 12 & 4.41 \\
\hline
\end{tabular}

\subsection{Reliability Analysis}

Reliability analysis is measured by Cronbach's $\alpha$. In general $\alpha \geqq 0.6$, reliability of measurement item is significantly satisfactory. Incase of this study, reliabilities of all items are $\alpha \geqq 0.83$. So reliability is significantly satisfactory(<Table $3>$ ).

<Table 3> Results of Reliability Analysis

\begin{tabular}{|c|c|c|c|}
\hline Divided & Count & Num & Cronbach's $\boldsymbol{\alpha}$ \\
\hline Security & 4 & N01-V04 & 0.934 \\
\hline Convenience & 4 & N05-V08 & 0.938 \\
\hline Interactivity & 4 & N09-V12 & 0.851 \\
\hline Information provided & 4 & N13-V16 & 0.907 \\
\hline Rapidness & 4 & N17-V20 & 0.882 \\
\hline Reliability & 4 & N21-V24 & 0.856 \\
\hline Intimacy & 4 & N25-V28 & 0.832 \\
\hline Correctness & 4 & N29-V32 & 0.905 \\
\hline Satisfaction & 4 & N33-V36 & 0.884 \\
\hline Repurchase intention & 4 & N37-V40 & 0.883 \\
\hline
\end{tabular}

Construct validity was determined by assessing convergent validity and discriminant validity(Hair et al., 2006). Construct validity was established based on the factor loading estimates and construct reliabilities(Hair et al., 2006). All loading estimates are significant $(p<0.00)$, with the lowest at 0.738 and the highest at $0.976<$ Table $4>$ ).

<Table 4> Convergent Validity and Reliability

\begin{tabular}{|c|c|c|c|c|c|c|c|}
\hline Factors & Item & St.Est. & S.E. & t-value & p-value & CR & AVE \\
\hline \multirow{4}{*}{ Security } & V1 & 0.824 & - & - & - & \multirow{4}{*}{0.991} & \multirow{4}{*}{0.965} \\
\hline & V2 & 0.939 & 0.064 & 20.015 & $* * *$ & & \\
\hline & V3 & 0.875 & 0.064 & 17.922 & $\star \star \star *$ & & \\
\hline & V4 & 0.895 & 0.063 & 18.603 & *** & & \\
\hline \multirow{4}{*}{ Convenience } & V5 & 0.860 & - & - & - & \multirow{4}{*}{0.991} & \multirow{4}{*}{0.965} \\
\hline & V6 & 0.904 & 0.049 & 20.694 & $* \star *$ & & \\
\hline & V7 & 0.921 & 0.051 & 21.404 & *** & & \\
\hline & V8 & 0.875 & 0.052 & 19.412 & $* * *$ & & \\
\hline \multirow{3}{*}{ Interactivity } & V9 & 0.861 & - & - & - & \multirow{3}{*}{0.967} & \multirow{3}{*}{0.906} \\
\hline & V10 & 0.862 & 0.070 & 15.547 & $* \star *$ & & \\
\hline & V11 & 0.765 & 0.068 & 13.936 & $* * *$ & & \\
\hline \multirow{3}{*}{ Information provided } & V13 & 0.957 & - & - & - & \multirow{3}{*}{0.992} & \multirow{3}{*}{0.977} \\
\hline & V14 & 0.790 & 0.039 & 19.244 & *** & & \\
\hline & V15 & 0.972 & 0.028 & 35.348 & $* \star *$ & & \\
\hline \multirow{3}{*}{ Rapidness } & V17 & 0.960 & - & - & - & \multirow{3}{*}{0.992} & \multirow{3}{*}{0.976} \\
\hline & V18 & 0.790 & 0.041 & 19.410 & $* \star *$ & & \\
\hline & V19 & 0.976 & 0.027 & 37.248 & $* * \star$ & & \\
\hline \multirow{4}{*}{ Reliability } & V21 & 0.813 & - & - & - & \multirow{4}{*}{0.985} & \multirow{4}{*}{0.944} \\
\hline & V22 & 0.761 & 0.071 & 12.879 & $* * *$ & & \\
\hline & V23 & 0.738 & 0.076 & 12.453 & $\star \star * *$ & & \\
\hline & V24 & 0.785 & 0.076 & 13.321 & $* * *$ & & \\
\hline
\end{tabular}




\begin{tabular}{|c|c|c|c|c|c|c|c|}
\hline Factors & Item & St.Est. & S.E. & t-value & p-value & CR & AVE \\
\hline \multirow{3}{*}{ Intimacy } & V25 & 0.806 & - & - & - & \multirow{3}{*}{0.984} & \multirow{3}{*}{0.954} \\
\hline & V26 & 0.855 & 0.078 & 15.117 & *** & & \\
\hline & V27 & 0.839 & 0.073 & 14.856 & *** & & \\
\hline \multirow{4}{*}{ Correctness } & V29 & 0.769 & - & - & - & \multirow{4}{*}{0.990} & \multirow{4}{*}{0.960} \\
\hline & V30 & 0.873 & 0.071 & 15.324 & $* * *$ & & \\
\hline & V31 & 0.843 & 0.072 & 14.724 & *** & & \\
\hline & V32 & 0.879 & 0.074 & 15.441 & *** & & \\
\hline \multirow{4}{*}{ Satisfaction } & V33 & 0.759 & - & - & - & \multirow{4}{*}{0.988} & \multirow{4}{*}{0.955} \\
\hline & V34 & 0.841 & 0.075 & 14.178 & $* * *$ & & \\
\hline & V35 & 0.807 & 0.075 & 13.557 & $* * *$ & & \\
\hline & V36 & 0.837 & 0.073 & 14.094 & *** & & \\
\hline \multirow{3}{*}{ Repurchase intention } & V37 & 0.882 & - & - & - & \multirow{3}{*}{0.990} & \multirow{3}{*}{0.971} \\
\hline & V38 & 0.867 & 0.052 & 19.393 & $* * *$ & & \\
\hline & V39 & 0.879 & 0.053 & 19.866 & 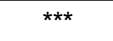 & & \\
\hline
\end{tabular}

<Table 5> Discriminant Validity

\begin{tabular}{|c|c|c|c|c|c|c|c|c|c|c|}
\hline & $\mathbf{1}$ & $\mathbf{2}$ & $\mathbf{3}$ & $\mathbf{4}$ & $\mathbf{5}$ & $\mathbf{6}$ & $\mathbf{7}$ & $\mathbf{8}$ & $\mathbf{9}$ & $\mathbf{1 0}$ \\
\hline Security & $\mathbf{0 . 9 6 5}$ & & & & & & & & & \\
\hline Convenience & .436 & $\mathbf{0 . 9 6 5}$ & & & & & & & \\
\hline Interactivity & -.221 & -.179 & $\mathbf{0 . 9 0 6}$ & & & & & & \\
\hline Information provided & .236 & .261 & -.301 & $\mathbf{0 . 9 7 7}$ & & & & & & \\
\hline Rapidness & .247 & .354 & -.233 & .445 & $\mathbf{0 . 9 7 6}$ & & & & \\
\hline Reliability & .036 & .181 & -.219 & .442 & .253 & $\mathbf{0 . 9 4 4}$ & & & \\
\hline Intimacy & .313 & .437 & -.339 & .392 & .401 & .345 & $\mathbf{0 . 9 5 4}$ & & \\
\hline Correctness & .282 & .286 & -.363 & .463 & .307 & .355 & .496 & $\mathbf{0 . 9 6 0}$ & \\
\hline Satisfaction & .459 & .580 & -.271 & .295 & .489 & .375 & .560 & .475 & $\mathbf{0 . 9 5 5}$ & \\
\hline Repurchase intention & .514 & .588 & -.287 & .565 & .593 & .393 & .625 & .521 & .703 & $\mathbf{0 . 9 7 1}$ \\
\hline
\end{tabular}

Note: The square root of AVE (italic at diagonal) and correlation coefficients.

\subsection{Discriminant Analysis}

Increase the goodness of fit of measurement model, the items V12, V16, V20, V28, V40 were deleted. The goodness of fit of the hypotheses yielded $X^{2}=779.798(d f=515, p=0.000$ ), $\mathrm{GFI}=0.864, \quad \mathrm{AGFI}=0.834, \quad \mathrm{NFI}=0.906, \quad \mathrm{IFI}=0.966, \quad \mathrm{CF}=0.966$, $\mathrm{RMSEA}=0.044$. This means that modified model is improved compared to initial one. So modified one became final one.

To ensure construct reliability, the squared correlation coefficients between any pair of constructs should be lower than the AVE for each construct(Hair et al., 2006). <Table $5>$ presents the correlation coefficients and square roots of AVEs, which indicate acceptable discriminant validity.

\subsection{Hypotheses Test}

Based on the final model, hypotheses analyses are performed with SPSS and AMOS. The results of this study are as follows. In general, $t$-value of C.R. $\geqq 1.96$, there are significant influence at $p=0.05$ level. <Figure $2>$ shows the estimates of structural equation model. The proposed model presents general acceptable fitnesses. Those are satisfactory to make hypotheses tests at significant level. Also the results are satisfactory(<Figure 2>). All hypotheses except $\langle\mathrm{H} 1-3\rangle,\langle\mathrm{H} 2-3\rangle$ are accepted. But $\langle\mathrm{H} 1-3\rangle,\langle\mathrm{H} 2-3\rangle$ are rejected. The detailed informations are shown $<$ Table $6>$. 
<Table 6> Hypotheses Results

\begin{tabular}{|c|c|c|c|c|c|}
\hline Path(Hypothesis) & Estimate & S.E. & C.R. & p-value & Result \\
\hline H1-1: security $\rightarrow$ satisfaction & 0.148 & .043 & 3.405 & *** & accepted \\
\hline H1-2: convenience $\rightarrow$ satisfaction & 0.185 & .046 & 4.047 & *** & accepted \\
\hline $\mathrm{H} 1-3:$ interactivity $\rightarrow$ satisfaction & 0.035 & .034 & 1.035 & 0.301 & rejected \\
\hline H1-4: information provided $\rightarrow$ satisfaction & 0.150 & .041 & 3.700 & *** & accepted \\
\hline $\mathrm{H} 2-1$ : security $\rightarrow$ repurchase intention & 0.218 & .046 & 4.760 & *** & accepted \\
\hline H2-2: convenience $\rightarrow$ repurchase intention & 0.160 & .049 & 3.269 & $0.001^{* *}$ & accepted \\
\hline $\mathrm{H} 2-3$ : interactivity $\rightarrow$ repurchase intention & 0.016 & .037 & 0.430 & 0.667 & rejected \\
\hline $\mathrm{H} 2-4$ : information provided $\rightarrow$ repurchase intention & 0.098 & .044 & 2.208 & $0.027^{\star}$ & accepted \\
\hline H3-1: rapidness $\rightarrow$ satisfaction & 0.177 & 0.039 & 4.516 & *** & accepted \\
\hline H3-2: reliability $\rightarrow$ satisfaction & 0.119 & 0.054 & 2.208 & $0.027^{*}$ & accepted \\
\hline H3-3: intimacy $\rightarrow$ satisfaction & 0.128 & 0.053 & 2.425 & $0.015^{\star}$ & accepted \\
\hline H3-4: correctness $\rightarrow$ satisfaction & 0.112 & 0.055 & 2.035 & $0.042^{*}$ & accepted \\
\hline H4-1: rapidness $\rightarrow$ repurchase intention & 0.119 & 0.042 & 2.810 & $0.005^{\star *}$ & accepted \\
\hline H4-2: reliability $\rightarrow$ repurchase intention & 0.153 & 0.058 & 2.619 & $0.009^{\star *}$ & accepted \\
\hline H4-3: intimacy $\rightarrow$ repurchase intention & 0.120 & 0.058 & 2.076 & $0.038^{*}$ & accepted \\
\hline H4-4: correctness $\rightarrow$ repurchase intention & 0.122 & 0.060 & 2.025 & $0.043^{*}$ & accepted \\
\hline H5 : satisfaction $\rightarrow$ repurchase intention & 0.175 & .074 & 2.360 & $0.018^{*}$ & accepted \\
\hline
\end{tabular}

*: $p<0.05, * *: p<0.01, * * *: p<0.001$, significant level.

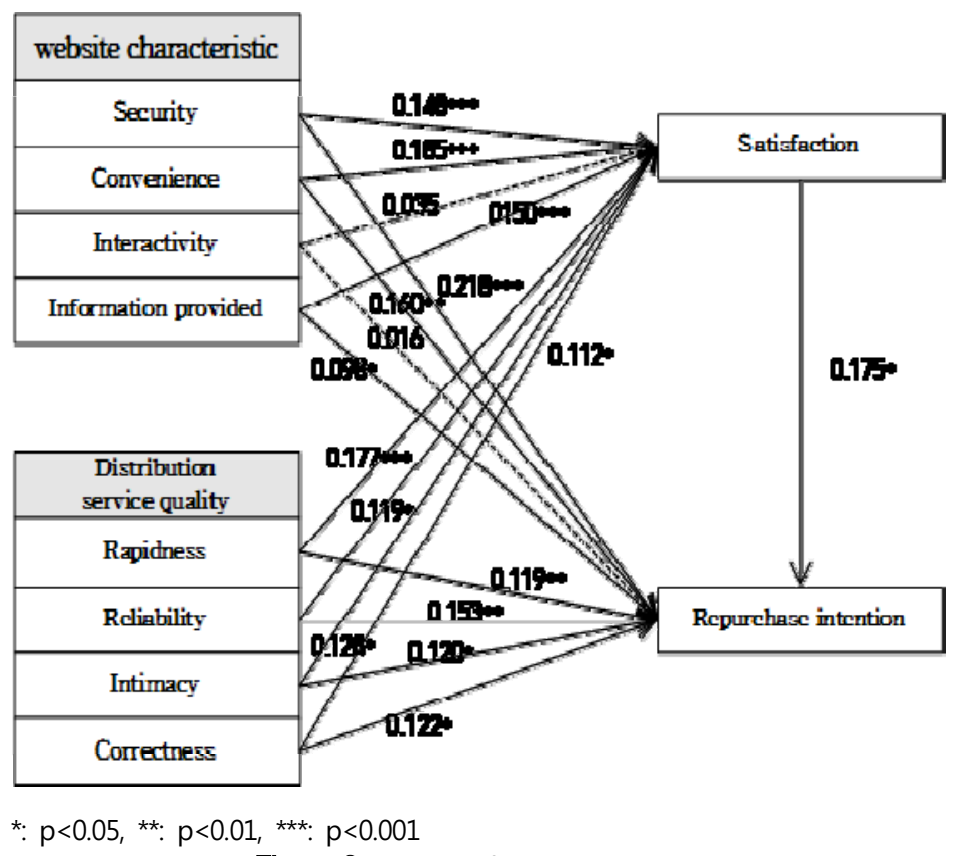

<Figure 2> Result of measuring model

\section{Conclusions and Limitations}

\subsection{Conclusions}

The results of this study are as follows.
First, Among the characteristics of the overseas direct purchase website, the security, convenience and information provided by the overseas direct purchase have already had a positive impact on the satisfaction. In particular, the safety of overseas direct purchase sites has shown the most 
significant impact on satisfaction, which means that with the technological development of overseas direct purchase sites, the improvement of customers' satisfaction and the re-purchase intention has produced greater importance.

Second, The quality of the delivery service is composed of four factors: rapidity, reliability, intimacy and correctness. From the verification results, the quality of delivery service has positive effect on the satisfaction and the re-purchase intention.

Third, The research results indicate that the satisfaction level has a positive impact on the re-purchase intention. And the users of overseas direct purchasing sites who are satisfied with the services provided by the website will also increase their intentions of the re-purchasing.

The significance of this study has the characteristics of overseas direct purchase sites which have confirmed that security convenience and intelligence availability have a positive impact on satisfaction and re-purchase intent. It is important to have a safe and reliable access to shopping sites on overseas direct purchase sites. In the characteristics of overseas direct purchase sites, the interaction have no positive effect on satisfaction and re-purchase intention. But the interaction with consumers in the exchange of customer service questions and comments will be accompanied by emotional communication. This kind of emotional communication has a certain impact on the shopping itself. The quality of the delivery service of the overseas direct purchase website is composed of four factors: rapid trustworthiness and correctness, and it is confirmed as positive (+) influence on the customers' satisfaction and repurchase. Overseas direct purchase sites' delivery management makes the constant pursuit of marketing strategies, in order to highlight the quality of services to provide continuous efforts. With the service customer satisfaction in the overseas direct purchase sites, it also brought the results of the repurchase. Therefore, the manager should ensure that through the improvement of services, it will improve service users' satisfaction and improve the degree of the re-purchase.

\subsection{Limitations and Future Research}

Limitations of the study and directions for future research are presented.

First, the study accounted for most of the sample of women aged 20 to 30 and office workers. Future research will examine the entire consumer sector, and through the sample of all ages and target industries, consumers will systematically expand the overall analysis of the respondents.

Second, although the study characteristics of overseas direct purchase website is convenience and security information, the interaction of four factors, future research, research review, according to the overseas direct purchase of the characteristic of the website service wide area before, it is necessary to study a variety of other factors.

Finally, the current international trend of direct purchase website is showing a rapid development trend. After that, the research will compare the direct purchase websites of China and Korea as well as the cultural and social characteristics of China and korea.

\section{References}

Bai, T., Rho, T. S., \& Nam, I. W. (2016). Analysis of Antecedents to Customer Satisfaction in Cross-Border E-Commerce. Korea E-Trade Research Institute, 14(3), 1-23.

Cho, H., Kim, K. H., \& Byun, S. H. (2014). Analysis on Overseas Direct Purchasing Utilizing Global Online Shopping Mall (B2C). The e-business Studies, 15(4), 343-361.

Hair, J. F., Anderson, R. E., Tatham, R. L., \& Black, W. C. (2006). Multivariate Data Analysis with Readings (6th ed.). New Jersey: Prentice Hall.

Hong, J. Y., \& Park, S. K. (2017). A Study on the Current State of Overseas Direct Sales and Strategic Activation Plans for Korea's SME. The Journal of Humanities and Social Science, 8(4), 793-808.

Kim, C. B., Min, C. H., \& Park, S. A. (2016). A Empirical Study on Determinants Affecting the Participation and Performance of Small and Medium-Size Enterprises in Global Electronic Commerce. Korea Association for International Commerce and Information, 18(4), 3-29.

Kim, C., Yang, H., \& Jung, J. (2017). Analysis of E-commerce Companies' Efficiency for Suggesting Distribution Companies How to React to an Increase in Global Sales. Journal of the Korean Operations Research and Management Science Society, 42(4), 53-66.

Kim, E. J., \& Park, J. (2016). Consumer's Overseas-DirectPurchase Behavior: Combining Technology Acceptance Model and Regulatory Focus Theory. Journal of Institute for Social Sciences, 274), 47-66.

Kim, S., \& Lim, J. W. (2015). The Effects of Consumer Characteristics on the Use of Cross-Border E-Commerce. Korea trade review, 4a4), 21-39.

Lee, Y., Ryu, M., \& Lee, S. (2015). A Study of Consumer Attitudes and Usage Intentions toward Overseas Direct Online Shopping: Focusing on the Extended Technology Acceptance Model. Korean Society of Consumer Studies, 26(5), 201-222.

Lim, G. G., \& Hong S. C. (2017). Classification and Analysis for the Business Models of Reverse Overseas Direct Purchasing. Journal of Information Technology Applications \& Management, 24(1), 93-110.

Shin, K. J. (2015). A Study on Resolution Methods of Overseas Direct Purchase Dispute by ODR. Journal of Arbitration Studies, 251), 3-23. 
Suk, K. H. (2016). Protection of Consumers in Disputes Arising from Internet Purchases (so-called "Overseas Direct Purchase"): With a Focus on the Private International Law Act, the Arbitration Act and the Standard Terms and Conditions Regulation Act. Seoul Law Journal, 573), 73-133.

Tian, X. F., \& Lee, J. H. (2016). A Study on Continuous Use Intention of Hotel $\mathrm{O} 2 \mathrm{O}$ Application Characteristics in China. Korean Journal of Hospitality and Tourism, 25(7), 35-50.

Tian, X. F., Wu, R. Z., \& Lee, J. H. (2017). Use Intention of Chauffeured Car Services by $\mathrm{O} 2 \mathrm{O}$ and Sharing Economy. Journal of Distribution Science, 15(12), 73-84.

Wu, R. Z., \& Lee, J. H. (2017). The Comparative Study on Third Party Mobile Payment Between UTAUT2 and TTF. Journal of Distribution Science, 15(11), 5-19.

Wu, R. Z., \& Lee, J. H. (2017). The Use Intention of Mobile Travel Apps by Korea-Visiting Chinese Tourists. Journal of Distribution Science, 15(5), 53-64.

Wu, R. Z., \& Lee, J. H. (2017). Use Intention of Mobile Fingerprint Payment between UTAUT and DOI in China. Journal of Distribution Science, 15(10), 15-28.

Wu, R. Z., \& Lee, J. H. (2016). The Effects of Repurchase Intention by Social Commerce Traits and Consumer's Traits in China. Journal of Distribution Science, 14(5), 97-106. 